\title{
The applicability of Bolton's tooth size ratios to Chhattisgarh population in India
}

\author{
Priyanka P. Niranjane ${ }^{1, *}$, Pallavi. S. Diagavane ${ }^{2}$, Sonali C. Shelke ${ }^{3}$ \\ ${ }^{1,2}$ Associate Professor, ${ }^{3}$ Consultant, Dept. of Orthodontics \& Dentofacial Orthopedics, Sharad Pawar Dental College \& Hospital, \\ (DMIMS) (Deemed to be University) Sawangi (M) Wardha, Maharashtra, India
}

*Corresponding Author:

Email: drpriyankaniranjane@yahoo.com

\begin{abstract}
Objective: The present study was undertaken to assess whether Boltons ratio can be applied to Chattisgarhi population and if values obtained are significantly different from that of Boltons established values, then to establish Boltons standards for the Chhattisgarhi population and also to determine if sexual dimorphism exists in overall and anterior ratios.

Study Design: 120 subjects (60 male and 60 female) between 17-25 years of age having normal occlusion were selected. Boltons anterior and overall ratio was calculated on study models and values obtained were statistically analyzed for co-efficient of variation, standard deviation and mean values. This data was compared with standard Bolton's values.

Results: The combined anterior and overall ratios of Chhattisgarhi population did not differ significantly from that of Boltons sample, however significant sexual dimorphism was noted both in anterior and overall ratios among males and females. Conclusion: Boltons anterior and overall tooth size ratios can be applied to Chhattisgarhi population.
\end{abstract}

Keywords: Bolton ratio, Chhattisgarhi population.

\section{Introduction}

A tooth size discrepancy (TSD) conventionally is defined as a disproportion among the sizes of individual teeth. For proper alignment and to achieve a good occlusal interdigitation of the dentition, the tooth size must be in harmony with the arch size (the sum of width of mandibular teeth must be smaller than the sum of width of maxillary teeth. ${ }^{1}$ This ratio of maxillary and mandibular tooth sizes represents an important aspect at initial stage of diagnosis and treatment planning of an individual. $^{2}$ If discrepancy goes undetected initially, it may be difficult to achieve an ideal occlusion at the end of treatment.

The first investigation of mesiodistal width was done by G.V Black in 1902. He measured a large number of human teeth and from these measurements he set up tables of mean figures which are still used as important references today. Different methods have been described to evaluate interarch tooth size relationship such as Keslings diagnostic set up, Neffs anterior coefficient etc, but the classical work done by Bolton in 1958 is most acceptable and most widely used. He evaluated 55 cases with excellent occlusions and developed two ratios for estimating TSD by measuring the summed mesiodistal (MD) widths of mandibular to maxillary teeth. ${ }^{3}$

Although Bolton analysis has proven extremely useful in clinical setting to act as a guide for extreme TSD, its application is not without limitations. First, Bolton's estimates of variation were underestimated because the samples were derived from perfect Class I occlusions (Crosby \& Alexander 1989; 4 Freeman et al. $1996^{5} \&$ Smith et al 2000. ${ }^{6}$ Second, the population and gender composition of Bolton's sample were not specified, which implies potential selection bias (Smith et al. 2000). ${ }^{6}$
Bolton data has not met the same TSD ratios mean with marked statistical differences found in studies carried out by authors in the Peruvian population (Bernabě et al. 2004), ${ }^{7}$ Turkish (Uysal \& Sari 2005), ${ }^{8}$ Spanish (Paredes et al. 2006) ${ }^{9}$ and Polish population (Wedrychowska-Szulc et al. 2010). ${ }^{10}$ As for Asian population, Bolton's anterior ratio was not applicable to the Southern Chinese (Ta et al. 2000) ${ }^{11}$ and Japanese population (Endo et al. 2007) ${ }^{12}$ and suggested the need for specific standard tooth size ratios for these populations.

Different tooth sizes have been associated with different ethnic groups, so it is logical to expect that differences in tooth widths can directly affect tooth width ratios. $^{2}$ Most studies indicated that normal measurements for one group should not be considered normal for other race and ethnic groups and so each racial group must be treated according to their own characteristics. The Bolton's analysis is considered a good indicator for evaluating the degree of intermaxillary tooth size harmony but it would be of clinical interest to examine the ethnic variation in particular population group.

Gender differences in tooth size have been reported in literature and may have clinical relevance. Male teeth are generally recognized to be larger than female teeth. Smith SS et al concluded that interarch tooth size relationships are population and gender specific. ${ }^{6}$ Arya et al also showed differences in tooth size between sexes. ${ }^{13}$ The dental literature is replete with studies that include sexual dimorphism to compare tooth size discrepancy. There is also a lack of agreement regarding gender differences in relation to tooth size proportion between upper and lower anteriors and so additional data is necessary to understand this relationship. $^{2}$ 
Chhattisgarh is a recently formed state in central India and till date no study exists regarding tooth size ratios in Chhattisgarhi population. As tooth size differences tend to be population specific, this study was undertaken to develop a set of normal values for Chhattisgarhi population and to test the validity and to assess the applicability of Boltons ratios in Chattisgarhi population.

We hope that such a study on the Chhattisgarhi population might help in better diagnosis and treatment planning as well as in prognosis and stability of treatment results.

\section{Aim and objectives}

1. To obtain the anterior and overall interarch tooth size ratios according to Boltons method in Angle class I normal occlusion in Chhattisgarhi young adults.

2. If values obtained are significantly different to that of Boltons established values, the aim will be to establish Boltons standards for the Chhattisgarhi population.

3. To compare the overall and anterior ratios between males and females to see if there is any sexual dimorphism.

4. Comparison of values obtained to that of Boltons normal values and of studies from other population groups.

\section{Materials and Methods}

In the present study 120 subjects (60 male and 60 female) between 17-25 years of age having normal occlusion were selected randomly from student community of Maitri Dental College and Hospital, Durg, Chhattisgarh, India. Informed consent was obtained from all the subjects participating in the study.

\section{Criteria for Sample Selection}

1. All subjects belonged to Chhattisgarhi ethnicity, residing in Chhattisgarh, which was confirmed from their family history.

2. A fully erupted permanent dentition from second molar to second molar with all first molars erupted

3. Class I molar and canine relationship, well aligned upper and lower arches with normal overjet and overbite.

4. Normal curve of spee

5. Normal morphology of teeth with no gross restorations, buildups, crowns, onlays, class II amalgams or composite restorations that affect the tooth mesiodistal diameter.

6. Subjects with no previous history of orthodontic treatment

7. Subjects with slipped contacts, minor rotations or insignificant deviations from ideal occlusion were included in the study.

8. No previous history of disease which could affect craniofacial growth and development.
Method of Study: Impressions were made of the selected subjects, and study models prepared. The mesiodistal dimension of each tooth was measured according to the method described by Moorrees et al. (1957), ${ }^{14}$ i.e from mesial contact point to distal contact point of each tooth by using the electronic digital calipers (Digimatic Caliper, Mitutoyu) accurate to 0.01 $\mathrm{mm}$ with the caliper tips held perpendicular to the long axis of each tooth. All measurements, carried out under natural light, were performed by the same examiner, who did not exceed more then eight casts per day in order to avoid eye fatigue and to minimize the possibility of subjective error. The mesiodistal widths from the contact points of canine to canine for anterior ratio and first molar to first molar for overall ratio were made. The reading was recorded at the $0.1 \mathrm{~mm}$ level, and the same examiner made all measurements. The measurements were cross checked to avoid technical errors. Goose (1963) suggested that the mesiodistal diameter axis should run between the contact points of the tooth crown with its neighbours, in normal occlusion. ${ }^{15}$ In cases of malocclusion, the positions on the crown at which the contact points would have been in normal occlusion were used. In case of a rotated tooth the mesiodistal measurement was made diagonally while in case of lingually inclined tooth the mesiodistal measurement was taken lingually.

The total and anterior ratios were determined by Bolton's formula [3]:

Total ratio $(\%)=\underline{\text { sum of mandibular ' } 12 \text { ' x } 100}$ sum maxillary ' 12 '

Anterior ratio $(\%)=\underline{\text { sum of mandibular ' } 6 \text { ' } \times 100}$ sum maxillary ' 6 '

The values obtained were statistically analyzed for co-efficient of variation, standard deviation and mean values. This data is to be compared with standard Bolton's values.

\section{Observation and Results}

The overall ratio for Chattisgarhi sample is $91.96^{{ }^{+}}$ 2.14; while the anterior ratio is $77.68-^{-} 1.62$ respectively (table 1). There was no statistically significant difference in the anterior and overall ratio for Chhattisgarhi sample when compared with Boltons standards. However sexual dimorphism was observed as the values obtained for anterior and overall ratios for males and females showed statistically significant difference. The anterior and overall ratio of Chhattisgarhi sample was also compared with other population groups (Tables 2, 3, 4 and 5). From stepwise regression analysis the mandibular canines were found to have the greatest influence on the variation of both anterior and overall ratios. 
Table 1: Overall and Anterior ratios of Chhattisgarhi sample

\begin{tabular}{|c|c|c|c|c|c|c|}
\hline Parameter & \multicolumn{3}{|c|}{ Overall ratio } & \multicolumn{3}{c|}{ Anterior ratio } \\
\hline Sample & $\mathrm{M} \mathrm{(60)}$ & $\mathrm{F}(60)$ & Total (120) & $\mathrm{M}(60)$ & $\mathrm{F}(60)$ & total $(120)$ \\
\hline Mean & 92.47 & 91.45 & 91.96 & 78.03 & 77.33 & 77.68 \\
\hline SD & 1.959 & 2.218 & 2.142 & 1.655 & 1.528 & 1.621 \\
\hline Range & $87.8-97.3$ & $87.5-94.9$ & $87.5-95.3$ & $71.8-80.8$ & $75.1-80.8$ & $71.8-80.80$ \\
\hline $\begin{array}{c}\text { Cofficient of } \\
\text { variation }\end{array}$ & 3.838 & 4.924 & 4.589 & 2.742 & 2.335 & 2.629 \\
\hline $\begin{array}{c}\text { Standard } \\
\text { error }\end{array}$ & 0.3098 & 0.350 & 0.239 & 0.261 & 0.241 & 0.181 \\
\hline T test & \multicolumn{2}{|c|}{2.17} \\
$(\mathrm{p}=0.03<0.05)$ & & \multicolumn{2}{c|}{$\begin{array}{c}1.96 \\
(\mathrm{p}=0.05)\end{array}$} \\
\hline
\end{tabular}

Table 2: Statistical comparison between Chattisgarhi sample versus other population groups (Anterior ratio)

\begin{tabular}{|l|c|c|c|c|c|c|}
\hline \multicolumn{1}{|c|}{ parameter } & $\begin{array}{c}\text { Chattisgarhi } \\
\text { sample }\end{array}$ & $\begin{array}{c}\text { Boltons } \\
\text { (Caucasians) }\end{array}$ & $\begin{array}{c}\text { Paredes et al } \\
\text { (Spanish) }\end{array}$ & $\begin{array}{c}\text { Nie and Lin } \\
\text { (Hans } \\
\text { Chinese) }\end{array}$ & $\begin{array}{c}\text { Smith et al } \\
\text { (Blacks) }\end{array}$ & $\begin{array}{c}\text { Barnabe et al } \\
\text { (Peruvians) }\end{array}$ \\
\hline Sample & 120 & 55 & 100 & 60 & 60 & 100 \\
\hline Mean & 77.68 & 77.2 & 78.32 & 81.52 & 79.3 & 78.09 \\
\hline Range & $71.8-80.80$ & $74.5-80.4$ & - & - & - & - \\
\hline S.D & 1.621 & 1.65 & 2.45 & 2.82 & - & 1.53 \\
\hline $\begin{array}{l}\text { Coefficient of } \\
\text { variation }\end{array}$ & 2.629 & 2.14 & 3.13 & 3.46 & - & 1.96 \\
\hline Standard error & 0.181 & 0.22 & 0.25 & 0.36 & - & 0.15 \\
\hline T test & & 1.67 & 2.10 & 9.44 & 6.72 & 1.72 \\
\hline & & $\mathrm{P}=0.09$ & $\mathrm{P}=0.04$ & 0.000 & 0.000 & 0.08 \\
\hline $\begin{array}{l}\text { NS- non } \\
\text { significant }\end{array}$ & & $\mathrm{NS}, \mathrm{p}>0.05$ & $\mathrm{~S}, \mathrm{p}<0.05$ & $\mathrm{P}<0.0001 \mathrm{~S}$ & $<0.0001 \mathrm{~S}$ & $\mathrm{NS}, \mathrm{p}>0.05$ \\
\hline
\end{tabular}

Table 3: Statistical comparison between Chattisgarhi sample versus other population groups (overall ratio)

\begin{tabular}{|l|c|c|c|c|c|c|}
\hline parameter & $\begin{array}{c}\text { Chattisgarhi } \\
\text { sample }\end{array}$ & $\begin{array}{c}\text { Boltons study } \\
\text { (Caucasians) }\end{array}$ & $\begin{array}{c}\text { Paredes et } \\
\text { al } \\
\text { (Spanish) }\end{array}$ & $\begin{array}{c}\text { Nie and Lin } \\
\text { (Hans } \\
\text { Chinese) }\end{array}$ & $\begin{array}{c}\text { Smith et al } \\
\text { (Blacks) }\end{array}$ & $\begin{array}{c}\text { Barnabe et } \\
\text { al } \\
\text { (Peruvians) }\end{array}$ \\
\hline Sample & 120 & 55 & 100 & 60 & 60 & 100 \\
\hline Mean & 91.96 & 91.3 & 91.97 & 93.27 & 93.4 & 91.06 \\
\hline Range & $87.5-95.3$ & $87.5-94.8$ & - & - & - & - \\
\hline S.D & 2.142 & 1.91 & 2.12 & 2.46 & - & 2.04 \\
\hline $\begin{array}{l}\text { Coefficient of } \\
\text { variation }\end{array}$ & 4.589 & 2.09 & 2.31 & 2.66 & - & 2.24 \\
\hline Standard error & 0.239 & 0.26 & 0.21 & 0.32 & - & 0.20 \\
\hline T test & & 1.87 & 0.03 & 3.29 & 4.07 & 2.86 \\
\hline & & $\mathrm{P}=0.06$ & $\mathrm{P}=0.95$ & $\mathrm{P}=0.001$ & $\mathrm{P}=0.000$ & $\mathrm{P}=0.004$ \\
\hline & & $\mathrm{NS}, \mathrm{p}>0.05$ & $\mathrm{NS}, \mathrm{p}>0.05$ & $\mathrm{~S}, \mathrm{p}<0.05$ & $\mathrm{~S}, \mathrm{p}<0.05$ & $\mathrm{~S}, \mathrm{p}<0.05$ \\
\hline
\end{tabular}

Table 4: Statistical comparison between Chattisgarhi sample versus other population groups (Anterior ratio)

\begin{tabular}{|l|c|c|c|c|cc|}
\hline Parameter & $\begin{array}{c}\text { Chattisgarhi } \\
\text { sample }\end{array}$ & $\begin{array}{c}\text { Assamese } \\
\text { sample }\end{array}$ & $\begin{array}{c}\text { Himachali } \\
\text { (Singla Anil) }\end{array}$ & $\begin{array}{c}\text { Jaipur(Mridula } \\
\text { Trehan et al) }\end{array}$ & $\begin{array}{c}\text { Hyderabad (Hri } \\
\text { Prasad Rao) }\end{array}$ & $\begin{array}{c}\text { Indians } \\
\text { (Valiathan et } \\
\text { al) }\end{array}$ \\
\hline Sample & 120 & 70 & 100 & 100 & 200 & 50 \\
\hline Mean & 77.68 & 78.48 & 77.67 & 76.62 & 77.70 & 78.39 \\
\hline Range & $71.8-80.80$ & $70.54-85.71$ & $73.01-84.27$ & & 3.06 & - \\
\hline S.D & 1.621 & 2.81 & 2.17 & 3.58 & 0.216 & 0.39 \\
\hline $\begin{array}{l}\text { Standard } \\
\text { error }\end{array}$ & 0.181 & 0.34 & & & & 0.07 \\
\hline T test & & 2.09 & 0.03 & & 2.64 & 1.64 \\
\hline Remarks & & $\begin{array}{c}\mathrm{P}=0.04 \\
\mathrm{~S}, \mathrm{p}<0.05\end{array}$ & $\begin{array}{c}\mathrm{P}=0.97 \\
\mathrm{NS}, \mathrm{p}>0.05\end{array}$ & $\mathrm{P}=0.021 \mathrm{~S}, \mathrm{p}<0.05$ & $\mathrm{P}=0.93 \mathrm{NS}, \mathrm{p}>0.05$ & $\mathrm{P}=0.07$ \\
$\mathrm{NS}, \mathrm{p}>0.05$ \\
\hline
\end{tabular}


Table 5: Statistical comparison between Chattisgarhi sample versus other population groups (overall ratio)

\begin{tabular}{|l|c|c|c|c|c|c|}
\hline Parameter & $\begin{array}{c}\text { Chattisgarhi } \\
\text { sample }\end{array}$ & $\begin{array}{c}\text { Assamese } \\
\text { sample }\end{array}$ & $\begin{array}{c}\text { Himachali } \\
\text { (Singla Anil) }\end{array}$ & $\begin{array}{c}\text { Jaipur(Mridula } \\
\text { Trehan et al) }\end{array}$ & $\begin{array}{c}\text { Hyderabad } \\
\text { (Hri Prasad } \\
\text { Rao) }\end{array}$ & $\begin{array}{c}\text { Indians } \\
\text { (Valiathan et } \\
\text { al) }\end{array}$ \\
\hline Sample & 120 & 70 & 100 & 100 & 200 & 50 \\
\hline Mean & 91.96 & 91.12 & 92.42 & 91.24 & 92.5 & 93.46 \\
\hline Range & $87.5-95.3$ & $86.75-97.70$ & $87.67-97.92$ & & & - \\
\hline S.D & 2.142 & 2.09 & 2.10 & 2.87 & 2.17 & 2.76 \\
\hline $\begin{array}{l}\text { Standard } \\
\text { error }\end{array}$ & 0.239 & 0.25 & & & 0.153 & 0.39 \\
\hline T test & & 2.42 & 1.44 & 1.92 & 1.89 & 3.27 \\
\hline Remarks & & $\begin{array}{c}\mathrm{P}=0.016 \mathrm{~S}, \\
\mathrm{p}<0.05\end{array}$ & $\begin{array}{c}\mathrm{P}=0.14 \mathrm{NS}, \\
\mathrm{p}>0.05\end{array}$ & $\begin{array}{c}\mathrm{P}=0.08 \mathrm{NS}, \\
\mathrm{p}>0.05\end{array}$ & $\begin{array}{c}0.06 \mathrm{NS}, \\
\mathrm{p}>0.05\end{array}$ & $\begin{array}{c}0.000 \mathrm{~S}, \\
\mathrm{p}<0.05\end{array}$ \\
\hline
\end{tabular}

Graph 1: Overall and anterior ratios in Chhatisgarhi males and females

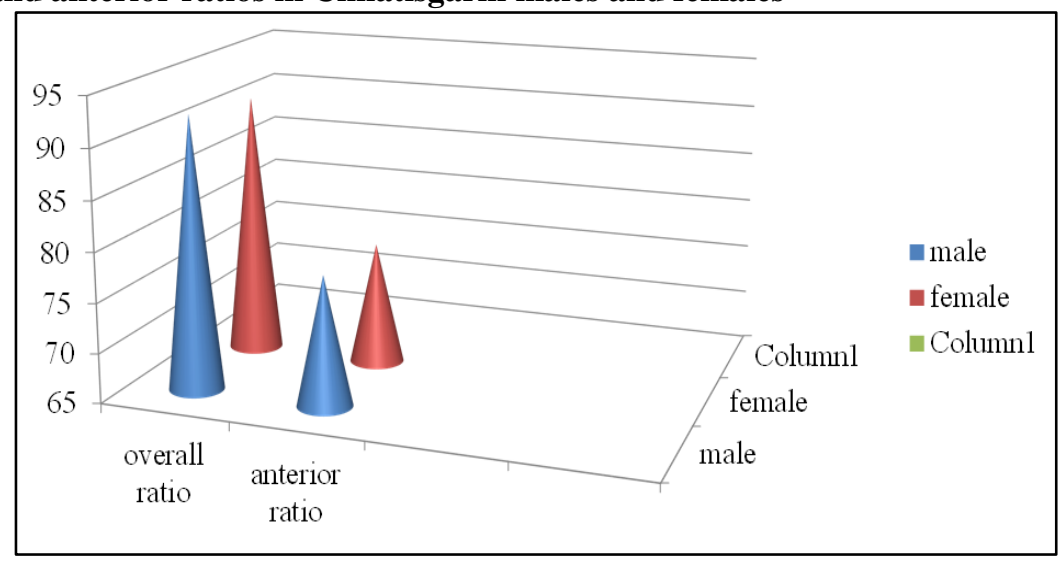

\section{Discussion}

In the present study, the mean overall ratio is 91.96 with S.D of 2.142 and mean anterior ratios is 77.68 with S.D of 1.621. The overall ratio and anterior ratio of Chhattisgarhi population did not differ significantly from Boltons sample. When compared with other population groups, the overall ratio was highly significantly lower than the Hans Chinese ${ }^{16}$ and Blacks ${ }^{6}$ but higher than the Peruvians. ${ }^{7}$ The anterior ratio of the Chhattisgarhi population was also highly significantly lower than the Hans Chinese and Blacks while statistically significantly less than the Spanish sample. ${ }^{9}$ Lavelle found that Blacks have larger overall and anterior ratios than Whites and Asians. ${ }^{17}$

The anterior and overall ratios were also compared with Indian population groups using Student $t$ test. It was observed that the anterior ratio in present study was significantly more than the Jaipur population. ${ }^{2}$ However no significant difference in anterior ratio was noted in Himachali 18, Hyderabad ${ }^{1}$ and (Indians) Valiathan sample. ${ }^{19}$ It was observed that the overall ratio in the present study was statistically significantly lower when compared with (Indians) Valiathan but higher than Assamese population. ${ }^{20}$ The overall ratio differed insignificantly when compared with Himachali, Hyderabad and Jaipur sample.

In the present study sexual dimorphism was noted between males and females in the anterior and overall ratios. The anterior and overall ratios showed statistically significant differences between males and females which was in contrast to Jaipur and Himachali ethnic population which showed no sexual dimorphism in anterior and overall ratios. Similarly no significant differences were observed in the anterior and overall ratios between males and females among Malaya dental students. $^{21}$

Lavelle showed that there was sexual dimorphism in tooth dimensions and in the ratio of upper and lower arch tooth sizes. ${ }^{17} \mathrm{He}$ showed that the overall and anterior ratios were consistently larger in males than in females, regardless of race, which correlates with our study. The tooth size data reported by Moorrees et $\mathrm{al}^{14}$ also imply gender differences in the overall ratio, which agrees with our findings.

Smith, Buschang, and Watanabe, evaluated Bolton's interarch ratios in three populations (i.e., Black, Hispanic, and White) and also evaluated the variation between genders. ${ }^{6}$ The anterior ratio $(77.26 \%)$ evaluated in our study is lower than that found by Smith, Bushang, and Watanabe for all the three populations, but the overall ratio $(91.34 \%)$ is higher in our study. Also, significant gender differences were observed for the overall ratio but not for the anterior ratio. 


\section{Conclusion}

1. The Boltons anterior and overall ratio for Chhattisgarhi population was $77.68 \%$ and $91.96 \%$ respectively.

2. The combined anterior and overall ratios of Chhattisgarhi population did not differ significantly from that of Boltons sample. Hence values for Boltons norms can be applied to Chhattisgarhi population

3. Significant sexual dimorphism was noted both in anterior and overall ratios among males and females.

\section{Conflict of Interest: None}

\section{Source of Funding: None}

\section{Ethical Clearance: Obtained}

\section{References}

1. Hari Prasad Rao G, Sharmila. Boltons norms for Hyderabad population Annals and Essences of Dentistry: Vol. 4(3), 70-79, 2012.

2. Mridula Trehan, Sonahita Aggarwal, Sunil Sharma. Applicability of Boltons analysis: A study on Jaipur population. International Journal of Clinical Pediatric Dentistry, 5(2):113-117, 2012.

3. Bolton WA. Disharmony in tooth size and its relation to the analysis and treatment of malocclusion. Angle Orthod; 28:113-130, 1958.

4. Crosby DR, Alexander CG. The occurrence of tooth size discrepancies among different malocclusion groups. Am J Orthod Dentofacial Orthop. 1989;95:457-461.

5. Freeman EJ, Maskeroni AJ, Lorton L. Frequency of Bolton tooth size discrepancies among Orthodontic patients. Am J Orthod Dentofacial Orthop. 1996;110:2427.

6. Smith SS, Buschang PH, Watanabe E. Interarch tooth size relationships of 3 populations: 'does Bolton's Analysis apply?' Am J Orthod Dentofacial Orthop.117; 169-74:2000.

7. Bernabe E, Major P W, Florice Mir C. Tooth width ratio discrepancies in a sample of Peruvian adolescents. Am J Orthod Dentofacial Orthop 125:361-365; 2004.

8. Uysal T, Sari Z. Intermaxillary tooth size discrepancy and malocclusion. Is there any relation? Am J Orthod Dentofacial Orthop. 2005;75:208-213.

9. Paredes V, Gandia J L, Cibrian R. Do Boltons ratios apply to a spanish population? Am J Orthod Dentofacial Orthop 129:428-430; 2006.

10. Wedrychowska- Szulc, B Janiszewska-Olszowska, J. and Stepien, P. 2010. Overall and anterior ratio in Class I, II, and III orthodontic patients. European Journal of Orthodontics 32: 313-318.

11. Ta T, ling $\mathbf{J}$ A, Hagg U. Tooth size discrepancies among different malocclusion groups of Southern Chinese children Am J Orthod; 120, 556-558, 2001.

12. Endo T, Sundo L, Abe R,Ishida K, Yoshino S, and Shimooka s. Applicability of Bolton tooth size ratios to a Japanese orthodontic population. Odontology 2007; 95:57-60.

13. Arya BS, Savara BS, Thomas D et al. Relation of sex and occlusion to mesiodistal tooth size. Am J Orthod 1974; $66: 479-486$.
14. Moorrees CFA, Thomsen SO, Jensen E. Mesiodistal crown diameters of the deciduous and permanent teeth in individuals. J Dent Res;36:39-47, 1957.

15. Sherwood R. Steadman. Predetermining the overjet and overbite. Angle Orthod: 19; 101-105, 1949.

16. Nie Q, Lin J. Comparison of intermaxillary tooth size discrepancies among different malocclusion groups. Am J Orthod Dentofacial Orthop. 1999; 116:539-544.

17. Lavelle CL. Maxillary and mandibular tooth size in different racial groups and in different occulasal categories. Am J Orthod 1972;61:29-37.

18. Singla Anil, Mahajan Monika. Boltons analysis of Himachali ethnic population Indian Journal of Dental Sciences. 2(4), 12-14, 2010.

19. Valaithan A, Krishna P K, Model analysis comparison of norms for Indian and Chinese using Boltons index. JIOS 25;77-80, 1994.

20. Dhar HCS, Bora M. The applicability of the Bolton's tooth size ratio to Assamese population. Journal of Indian Orthodontic Society 2010; 44: e38 URL:http://www.jiosweb.org.

21. S.A. Othman, H. Mookin, M.A. Asbollah, N.A. Hashim. Bolton tooth size discrepancies among University of Malaya's Dental students Annal Dent Univ Malaya.15 (1):40-47;2008. 